\title{
Seeing the forest through the trees: A meta-analysis of political budget cycles
}

\author{
Andrew Q. Philips*
}

August 21, 2016

Please cite as: Philips, Andrew Q. 2016. "Seeing the forest through the trees: A meta-analysis of political budget cycles." Public Choice. 168(3): 313-341.

\begin{abstract}
Despite a vast number of articles, the political budget cycle literature contains many conflicting theories and empirical results. I conduct the first ever meta-analysis of this literature in order to establish whether a link between elections and government budgets exists. Using data on 1198 estimates across 88 studies published between 2000 and 2015, I find evidence of a statistically significant—yet substantively small—increase in government expenditures and public debt around elections, and reductions in revenues and fiscal balance. Using meta-regression analysis combined with Bayesian model averaging, I find support for some of the context-conditional theories in the literature. Although the findings of political budget cycles are robust to publication bias as well as some of the methodological- and study-specific choices authors are forced to make, they also shed light on how certain decisions may affect a study's findings. This has implications for current and future research on political budget cycles.
\end{abstract}

Keywords: Political budget cycle; meta-analysis; fiscal policy

*aphilips@pols.tamu.edu. Ph.D Candidate, Department of Political Science, Texas A\&M University, 2010 Allen Building, 4348 TAMU, College Station, TX 77843-4348. I wish to thank Lorena Barberia, Guy D. Whitten, the editors and an anonymous reviewer for their comments and suggestions. Any errors and omissions remain my own. 
Do incumbents alter budgets before elections in order to secure the support of voters? Known as political budget cycles, research on this question has become a well-established literature in political economy. As of May 2016, a Google Scholar search for "political budget cycle" yields over 1000 results. Despite this large volume of studies, the theoretical underpinnings, empirical findings, and literature reviews of many articles often are at odds with one another. While some scholars have found substantial evidence that governments tend to increase expenditures around elections (Brender and Drazen 2005; Veiga 2012), others have found little to no such evidence (Vergne 2009; Katsimi and Sarantides 2012, Enkelmann and Leibrecht 2013). Although various fiscal instruments have been analyzed by scholars—-such as expenditures, revenues, fiscal balance, and public-sector debt—no theory establishes why incumbents might prefer one over the other. More disconcerting, well-argued theories often lead to opposing empirical expectations. For instance, while some scholars theorize that governments increase current transfers during elections at the cost of capital expenditures (Kneebone and McKenzie 2001; Gonzalez 2002; Vergne 2009), others argue that capital expenditures (commonly road or building construction) are more likely than current spending to increase before an election (Schuknecht 2000; Khemani 2004; Drazen and Eslava 2010). All of this begs the question: what do we know about political budget cycles, and how can we reconcile such a large body of literature?

To address this question I use a meta-analysis to conduct the first comprehensive overview of political budget cycle studies. This approach is gaining popularity in economics and political science, having been used to study the relationship between democracy and economic growth, (Doucouliagos and Ulubaşoğlu 2008), oil and democracy (Ahmadov 2014), the factors that influence voter turnout (Smets and Van Ham 2013), and partisan effects on spending (Imbeau et al 2001). Surprisingly, no quantitative meta-analysis has studied the relationship between elections and fiscal policies. By treating a regression coefficient from each model in each article as a single observation, this research design offers an ideal way of synthesizing all available information on 
political budget cycles.

This paper is motivated by the contexts that make political budget cycles more or less likely to occur. The broad notion that context matters is not new (Franzese 2002; Alt and Rose 2009; Dubois 2016). For instance, countries may have political budget cycles of greater frequency and larger amplitude if they are new democracies (Barberia and Avelino 2011), have less transparent fiscal policies (Alt and Lassen 2006a), or lack balanced-budget requirements (Rose 2006). However, attributing how changes in context affect the evidence for political budget cycles is difficult, given that empirical tests are conducted using different data sources, levels of aggregation, and econometric methods. Meta-regression analysis can account for these differences, thus giving us a cleaner assessment as to whether-and in what contexts-political budget cycles exist.

The meta-analytic approach is subject to two common critiques: a meta-analysis combines studies of varying quality, and it compares studies that are fundamentally incomparable owing to study-specific differences (e.g., methodology, data, controls). The first critique is easily addressed by weighting the studies by a measure of "quality", such as the impact factor of the journal in which the article was published, or by the number of citations it has received. The second critique is handled by accounting for any differences between studies that might explain variation in the sizes of estimated effects in a meta-regression analysis. Although excellent qualitative reviews exist (Franzese 2002; De Haan and Klomp 2013; Dubois 2016), by considering all empirical results published from 2000 to 2015, and by quantifying and controlling for observable differences between them, this paper is more systematic and takes into account more studies than is possible with a single literature review.

Using 1198 estimates from 88 studies, I find evidence that fiscal expenditures and government borrowings increase around elections, while revenues and fiscal balance decline. Although the magnitude of this effect is small, it remains robust to publication bias, which I find evidence of 
throughout the literature. I also test empirically how certain contexts may be influencing the results by accounting for data- and methodological-specific differences between studies. I find that a number of factors appear to be driving the differences in estimated effects, among them how the election is coded, whether elections are pre-determined, and if dynamics are addressed. After controlling for other confounders, I find evidence that a number of important factors influence the size of the political budget cycle effect, among them democracy and development. In contrast, others - such as electoral competition and ideology — do not. I also test for and find evidence of publication bias. A statistically significant political budget cycle remains even after accounting for this bias.

The rest of this paper is structured as follows. I first review the literature on political budget cycles. Next I discuss the research design and data collection. I then present calculated effect sizes across a variety of budgetary categories and sub-categories. Next I examine differences in the magnitudes of the political budget cycles by applying a meta-regression analysis. Finally, I discuss publication bias and conclude with a discussion of the implications of these findings.

\section{Political budget cycles: A review}

Political budget cycles developed out of the literature on opportunistic fiscal policies. According to this theory, politicians take advantage of the Phillips curve, or the negative relationship between inflation and unemployment (Nordhaus 1975). Early works posited that an incumbent will reduce unemployment rates before an election to appeal to voters, only to endure the impending rise in inflation after the election. Hibbs (1977) adapted this conjecture by theorizing how an incumbent may spend based on partisan preferences, thus explaining why left-leaning governments favor low unemployment, while right-leaning governments show concern about the growth rate of the money supply. After the paradigm shift towards rational expectations in political business cycles, a new 
wave of scholars began to focus on the short-run changes in fiscal expenditures around electionsthe theory being that these are used to deceive voters into believing that the economy is doing better than it actually is (Rogoff 1990; Persson and Tabellini 1990; Alesina and Roubini 1992). Out of this came two distinct literatures. One centered on budget cycles that governments create around elections. For the other, scholars of political business cycles focused on public-sector spending as well as monetary policy and growth. Since then, three broad trends have emerged in the literature on political budget cycles.

The first expanded the unit of analysis. While early studies tested theories in the United States or Western European democracies (Schultz 1995), the literature has moved on recently to developing countries, such as Brazil (Sakurai and Menezes-Filho 2011), Indonesia (Sjahrir et al 2013), or India (Sáez and Sinha 2010). Combinations of developed and developing countries have been studied in order to examine how other factors, such as the level of democracy and governmental transparency, affect political budget cycles (Brender and Drazen 2005; Shi and Svensson 2006; Klomp and De Haan 2013b), with the broad consensus being that countries with low levels of development, democracy and transparency tend to show more evidence of political budget cycles. Scholars also have begun to focus on elections held at intermediate (Galli and Rossi 2002; Khemani 2004) and local levels of government (Drazen and Eslava|2010; Veiga|2012; Aidt and Mooney 2014), although no theoretical argument has been advanced as to why such cycles may be stronger or weaker at different levels of government.

Second, scholars have theorized about contextual conditions in which political budget cycles may be more or less likely to occur (De Haan and Klomp 2013; Dubois 2016). For instance, fiscal transparency (Alt and Lassen|2006b), international oversight (Hyde and O’Mahony 2010), and fiscal stability rules (Rose 2006; Streb and Torrens 2013) may moderate budget deficits around elections. Poor economic conditions may make cycles more likely (Schultz 1995), as may election dates that are fixed (i.e., predetermined) rather than called "early" so that incumbents can take 
advantage of good economic news (Shi and Svensson 2006). These analyses contribute to the heterogeneous findings found in the literature. Thus, while the theoretical underpinnings of political budget cycles have become richer, comparing studies has become more difficult.

Third, the fiscal variable under analysis has become ever more disaggregated over time. Studies look at multiple budgetary instruments, such as revenues, expenditures, or debt (e.g., Rose 2006; Gonzalez 2002). Although highly aggregated fiscal categories, such as deficits or total expenditures, rise as elections draw near (Alt and Lassen 2006b), scholars now argue that disaggregated expenditures are more likely to be manipulated, since it is easier to allocate budgetary resources to a single spending category than to revise the entire public budget. Moreover, particular budget categories may be more visible to voters. For instance, infrastructure spending (Aidt et al 2011) and administrative expenditures (Enkelmann and Leibrecht|2013) have been shown to increase around elections.

How have these three shifts in the literature affected the evidence on political budget cycles? As analyses become more diverse in terms of their data, methodological, and theoretical sophistication, it becomes more difficult to explain why results differ across studies. This should not be seen as a disadvantage, since theories of political budget cycles are richer than ever, and tested in a growing number of countries and contexts. However, it makes comparisons between studies more problematic. Moreover, study-specific differences make it hard to identify the potential causes of changes in political budget cycle effects across studies. A meta-analysis addresses these challenges in two ways. First, it can establish whether an effect exists and, if so, whether it differs across contexts. Second, it allows us to parse out which specific data-, study- and methodology-specific choices influence the findings. 


\section{Research design}

To conduct a meta-analysis, I first created a specific set of criteria that had to be met for a study to be included in the current study 1 First, a search using the terms "political budget cycle" and "political business cycle" was conducted, using both Web of Science and Google Scholar, on articles published from 2000 to 2015 . Next, study titles, abstracts, and keywords were screened. For a study to proceed past that stage, it had to mention either political budget cycles or discuss a theoretical relationship between elections and a fiscal outcome. For instance, "the prevalence of electoral cycles in fiscal balance," in the abstract of Alt and Lassen (2006b, p. 530) made it eligible for inclusion. In addition, studies had to be published in English in peer-reviewed journals ${ }^{2}$ Borderline cases were included rather than excluded. All told, 232 studies passed the screening stage.

Next, studies that made it beyond the first screening had to meet the following set of eligibility criteria through a full-text reading. First, articles had to contain an empirical test, ruling out studies that included exclusively formal models or qualitative overviews of political budget cycles. Second, articles must have used a fiscal measure as a dependent variable, ruling out studies of monetary policy. While studies of monetary cycles are important, these dependent variables (typically output, inflation, and money growth) are too distinct from fiscal cycles to be included in a combined metaanalysis. Third, since the main variable of interest in studies of political budget cycles is the election, studies that did not include some form of election variable were dropped. Fourth, I did not include any studies that exclusively tested an interactive effect between elections and another covariate, since conditional coefficients are not directly comparable across studies. Instead, the meta-analysis below offers a way to tease out how important factors affect political budget cycles indirectly. Finally, an estimate of the size of the effect of elections on budgets had to be reported,

\footnotetext{
${ }^{1}$ Further details are in the Supplemental Materials.

${ }^{2}$ As have others (Doucouliagos and Ulubaşoğlu 2008), I did not include unpublished results. I address potential publication bias in the Supplemental Materials.
} 
along with an associated measure of statistical precision. A total of 88 studies were eligible for inclusion in the meta-analysis. Included studies, as well as the full list of excluded studies are available in the Supplemental Materials.

When conducting a meta-analysis, raw coefficients reported in a study must first be converted into an associated magnitude in order to make them comparable across studies (Stanley 2001, Borenstein et al 2011). One of the most useful metrics of standardized effects are partial correlation coefficients:

$$
\varepsilon_{i j}=\sqrt{\frac{t_{i j}^{2}}{\left(t_{i j}^{2}+d f_{i j}\right)}}
$$

where $\varepsilon_{i j}$ is the partial correlation coefficient of study $i$ and model $j, t_{i j}^{2}$ is the squared $t$-statistic from the regression, and $d f_{i j}$ represents the degrees of freedom (Stanley and Doucouliagos 2012) $!^{3}$ Since this calculation creates a positive $\varepsilon_{i j}$ by construction, it must be converted into a negative correlation if the $t$-statistic carried that sign, thus bounding $\varepsilon_{i j}$ between -1 and 1 . Alternatives to calculating partial correlations exist, such as "vote-counting" (a tabulation of significant and non-significant results), meta-probit analysis (Smets and Van Ham 2013), or a "success-rate" of hypothesized directions (Imbeau et al 2001). However, partial correlations are preferable since this technique accounts for the sampling error of the estimated effect by adding weights, as shown below (Stanley and Doucouliagos 2012).

The standard error of the partial correlation is given as

$$
S E_{i j}=\sqrt{\frac{1-\varepsilon_{i j}}{d f_{i j}}}
$$

Its inverse is used as a measure of estimate precision.

After obtaining partial correlations for each study, the total size of the political budget cycle

\footnotetext{
${ }^{3}$ Standard errors and p-values were converted into $t$-statistics if they were reported.
} 
effect can be obtained as follows:

$$
\varepsilon=\frac{\sum\left(N_{i j} \varepsilon_{i j}\right)}{\sum N_{i j}}
$$

where the size of the total effect, $\varepsilon$, is given by the sum of the partial correlations calculated in Equation 1 multiplied by an assigned weight $N_{i j}$ for each study, divided by the sum of the weights, $N_{i j}$. A number of weights can be assigned in Equation 3. Keeping with the dominant trend in economics and political science (Doucouliagos and Ulubaşoğlu 2008; Ahmadov 2014), I let $N_{i j}$ be the number of observations, although the results remain robust to two other forms of weightingsuch as the number of an article's citations, the journal's impact factor, and the inverse of the standard error of the partial correlation $4^{4}$

\section{Results}

To summarize the results of the partial correlations visually, I use funnel plots, shown in Figure 1. The calculated sizes of the 1198 models' partial correlations are shown on the the vertical axis, while the precision of the partial correlation (inverse of the standard error) is on the horizontal axis. I disaggregate the calculated partial correlations into four distinct groups:

- Expenditures are the most often-studied dependent variable, and constitute the largest category in the sample (699 of the 1198 study observations).

- Revenues are another important category in the literature, comprising 243 of the 1198 total observations. Evidence suggests that revenues tend to decline around elections (Barberia and Avelino 2011; Katsimi and Sarantides 2012; Aidt and Mooney 2014).

- Fiscal balances (revenues minus expenditures) show the net effect of elections on budgets,

\footnotetext{
${ }^{4}$ These results are available in the Supplemental Materials.
} 
and are not directly comparable to either expenditures or revenues. Out of the 1198 observations coded for this analysis, 234 were of fiscal balance 5

- Last, debt is a rarely studied (only 22 out of 1198 observations) dependent variable that is distinct from the other categories.

Expenditures

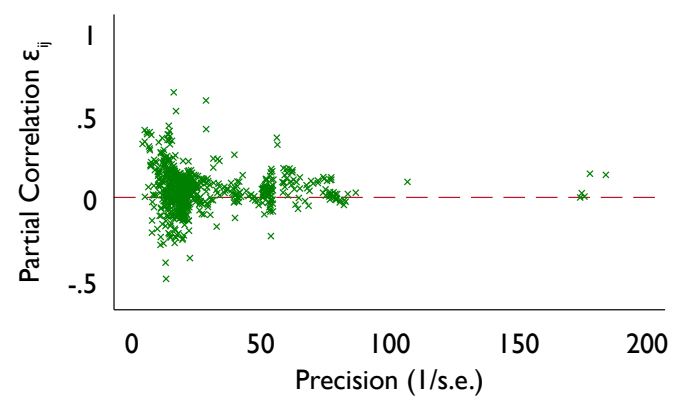

Fiscal Balance

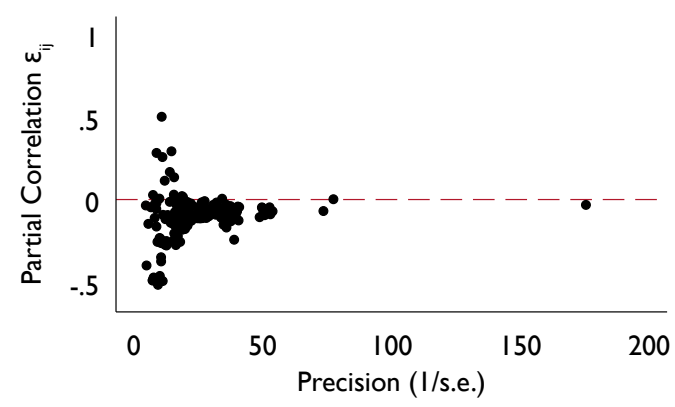

Revenues

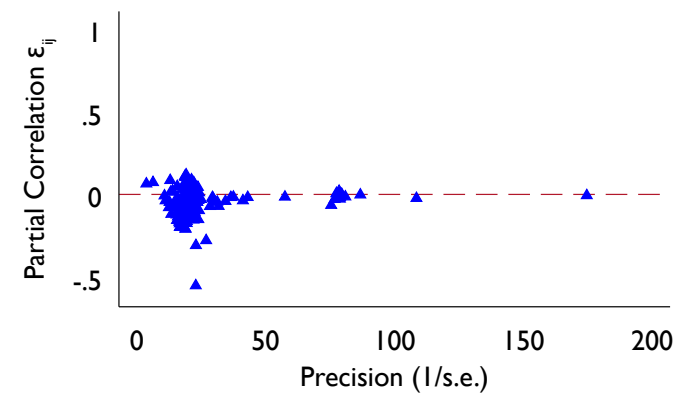

Debt

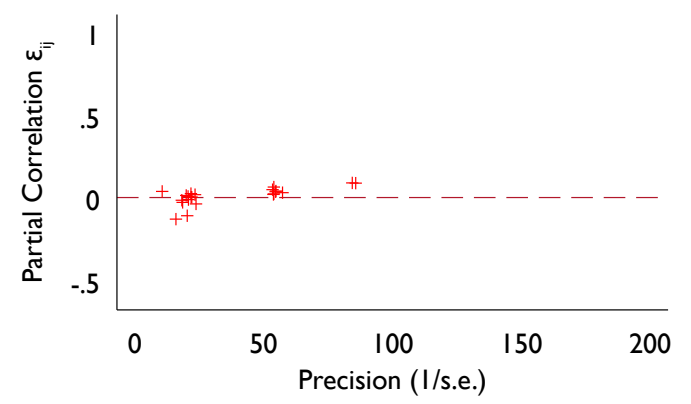

Figure 1: Funnel plots of the four budgetary categories Notes: 1198 total estimates for 88 studies.

As shown in Figure 1, expenditures tend to be above the horizontal dashed line. Since the calculated partial correlation is positive with an average of around 0.05 , this indicates that expenditures

\footnotetext{
${ }^{5}$ I recoded studies that examined deficit spending as their dependent variable, so that a positive partial correlation indicates an increase in fiscal surplus for all models.
} 
tend to increase in the election year. Although the effect lies in the expected positive direction, it is not large; Cohen (2013) suggests that a standardized effect is small if less than 0.10 , moderate if it is around 0.25 , and large if greater than 0.40 . With an average partial correlation of 0.01 , the same appears to be true for debt, although with only 22 observations the evidence is much less conclusive. In contrast to these two categories, revenues always tend to have negative calculated partial correlations, with an average of -0.05 . This suggests - in line with the literature-that revenues fall in an election year. The fiscal balance category shows a similar effect; calculated partial correlations tend always to be negative, indicating that deficit spending increases in election years. In fact, the average partial correlation for fiscal balance is -0.11 , about double the magnitude of the other types of dependent variables.

\subsection{Disaggregation and measures of uncertainty}

Based on Figure 1, expenditures and public debt appear to increase during an election year, and revenues and fiscal surpluses to decline. However, these are simple averages and do not take into account the precision associated with each calculated partial correlation. To examine this further, I plot calculations of magnitude in Figure 2, along with 95\% confidence intervals. Recall from Equation 3 that the size of an estimated effect, $\varepsilon$, is the sum of each partial correlation multiplied by an assigned weight (such as the number of observations), divided by the sum of the weights. Confidence intervals are calculated four ways. The first is an estimate of the unweighted effectanalogous to an unweighted average effect. Since the other three confidence intervals weight by the number of observations, the sizes of their effects are identical. However, the estimated effects differ in terms of how the error term is modeled. Confidence intervals calculated using random effects model the error as a function of a purely stochastic component, $u_{i j}$, as well as a studyspecific residual, $v_{j}$. In contrast, fixed effects do not allow for study-specific errors. The random effects model is almost always preferable to the fixed effects model since the latter is inappropriate 
if unexplainable heterogeneity remains in the true effect size; this is common in nearly all social science applications (Stanley and Doucouliagos 2012) 6 The final confidence interval calculation comes from Hunter and Schmidt (2004) and estimates the "heterogeneity variance by calculating the difference between the total variance of the effect estimates and an average of the estimated within-study variances" (Sánchez-Meca and Marín-Martínez 2008, p. 35).

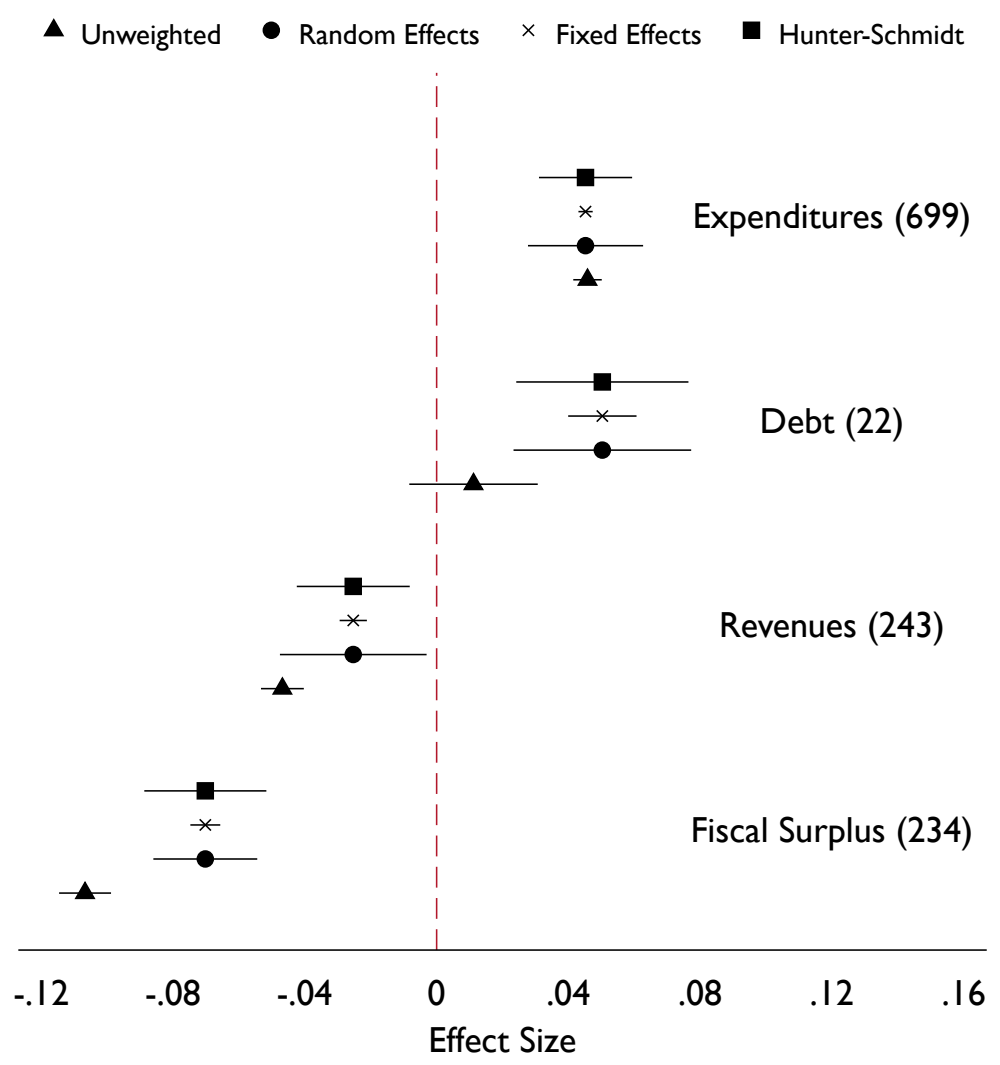

Figure 2: The political budget cycle effect across four major categories

Notes: Study-model observations in parentheses. 95\% confidence intervals reported.

\footnotetext{
${ }^{6}$ In fact, fixed effects often overstate our confidence in the coverage probability of the true effect (Sánchez-Meca and Marín-Martínez 2008, Borenstein et al 2011). This is formally tested through the Q-test; I was able to reject the null hypothesis of no heterogeneity.
} 
As shown in Figure 2, even after accounting for sampling error using random effects, fixed effects, or Hunter-Schmidt confidence intervals, a political budget cycle exists that is statistically significantly different from zero for all four types of dependent variable. The sizes of the effects of expenditures and debt are nearly identical, positive (albeit small), and around 0.05. This means that, taken as a whole, the literature finds statistically significant evidence that expenditures and debt increase in an election year. In contrast, scholars who have examined revenues and fiscal surplus tend to find a statistically significant negative relationship. Moreover, the magnitude of this effect appears to be about twice as large for fiscal surpluses as it is for revenues.

While Figure 2 showed evidence of a political budget cycle across the four broad categories of dependent variables, are certain types of expenditures and revenues more likely to be manipulated around elections? Much of the literature has focused on how the pre-election composition of spending may change (Vergne 2009, De Haan and Klomp 2013; Klomp and De Haan 2013a). For instance, visible budget items that appeal to a broad range of voters, such as social welfare policy (Chang 2008), may be more likely to increase prior to Election Day than a more narrow budget category like administrative expenditures. For revenues, tax breaks may be targeted to certain key voter constituencies (Khemani 2004).

To investigate whether certain budgetary categories may be driving the sizes of the effects reported above, I disaggregate the calculated effect sizes further, as other meta-analyses have done (Lau et al 2007). I divide the 243 revenue-study observations into three of the largest categories, and the 699 observations for expenditures into seven categories $]^{7}$ The results for revenue are shown in Figure 3. The overall effect of all 243 revenue observations is shown for reference at the top. I disaggregated revenues into studies that modeled total revenues, those that explicitly modeled tax revenues, and those that modeled "other" types of revenues (mostly non-tax sources). It is clear from Figure 3 that studies of total revenue tend to have the largest negative relationship with

\footnotetext{
${ }^{7}$ A detailed breakdown of these categories is in the Supplemental Materials.
} 
elections. Tax revenues, such as those on income and property, have an estimated effect size of -0.03 , while those for other revenue sources are not statistically significantly different from zero. Taken together, this evidence suggests that total revenues and tax revenues tend to decline the most around elections. Non-tax revenues do not appear to be manipulated around Election Day.

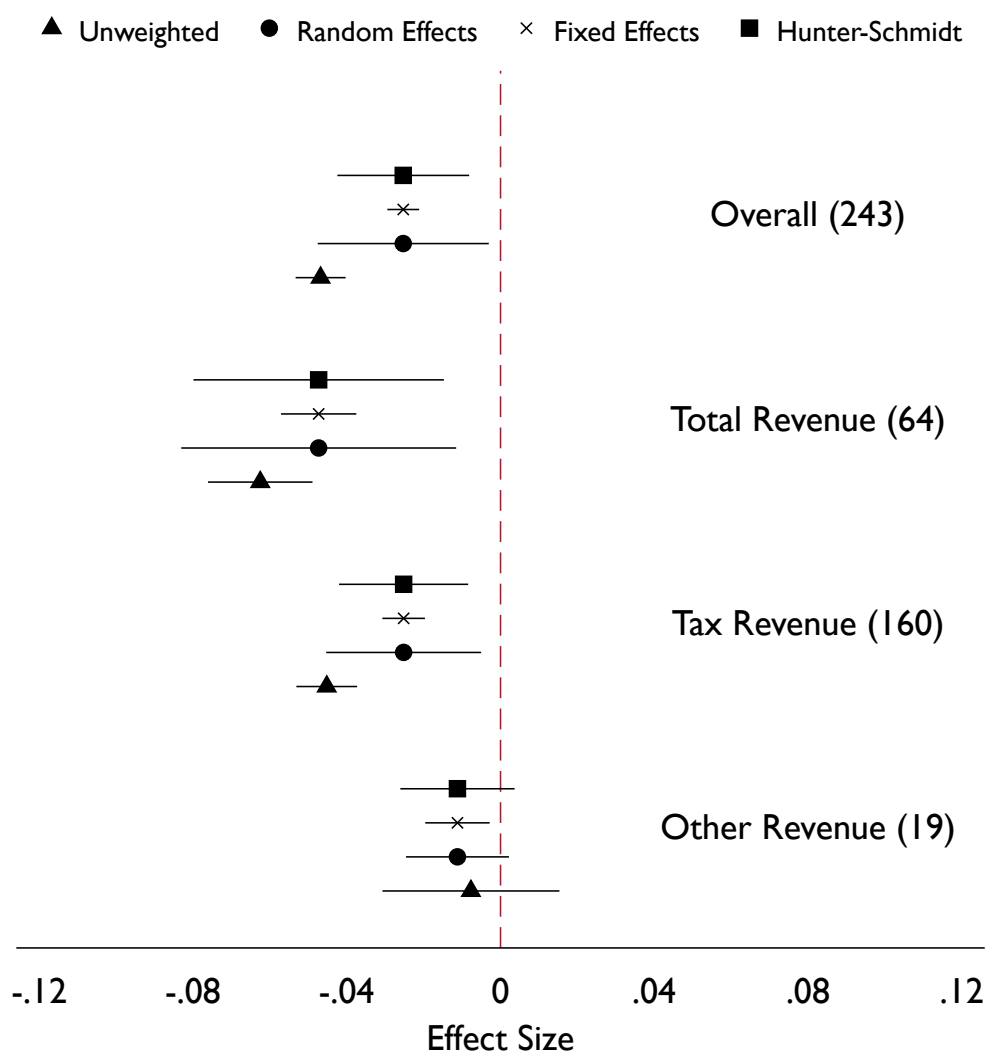

Figure 3: The political budget cycle effect: Revenue disaggregation Notes: Study-model observations in parentheses. 95\% confidence intervals reported.

In Figure 4, I show the size of the overall effect for expenditures as well as the seven largest sub-categories: inter-governmental grants, total expenditures, administrative expenditures, education and health expenditures, capital expenditures, other, and current expenditures. As with 
revenues, substantial differences are evident in the political budget cycle effect, depending on the fiscal variable considered. The strongest evidence of an effect in Figure 4 appears to be for intergovernmental grants. For instance, Veiga (2012) reports evidence that grants from the European Union to Portuguese municipalities tend to increase during election years. John and Ward (2001) find that central government grants to UK local authorities increase in election years, and Padovano (2012) finds a similar effect for Italian regions. Overall, the estimated effects of intergovernmental grants are more than double the overall effect. For studies that use total expenditures as a dependent variable, the effect is slightly larger than the overall effect, although some overlap is evident after accounting for sampling error.

The last five categories presented towards the bottom of Figure 4 include some of the most disaggregated components of spending that have been studied in the literature. In fact, theories about "visible" expenditures suggest that capital and current expenditures are some of the most likely budget categories to be manipulated. This makes the finding that these fiscal categories have some of the weakest evidence for a political budget cycle effect notable. The findings here may be explained best by the conflicting state of the literature. Some authors find that capital expenditures, which typically create some form of asset in a one-time event, tend to increase before elections (Schuknecht 2000; Khemani 2004; Drazen and Eslava 2010). In contrast, others find that current expenditures, which involve ongoing payments, such as salaries or subsidies, are more susceptible (Kneebone and McKenzie 2001; Gonzalez|2002; Katsimi and Sarantides|2012). Such inconclusive results are clear in this analysis as well. Neither category tends to be statistically significantly different from zero once sampling error is accounted for, though the effect for capital expenditures is slightly larger. Thus, it appears that neither category is consistently manipulated as a more visible form of spending.

Administrative expenditures also have an effect that tends to overlap zero. Such uncertainty is apparent in the literature; examining administrative expenditures, Drazen and Eslava (2010) find a 


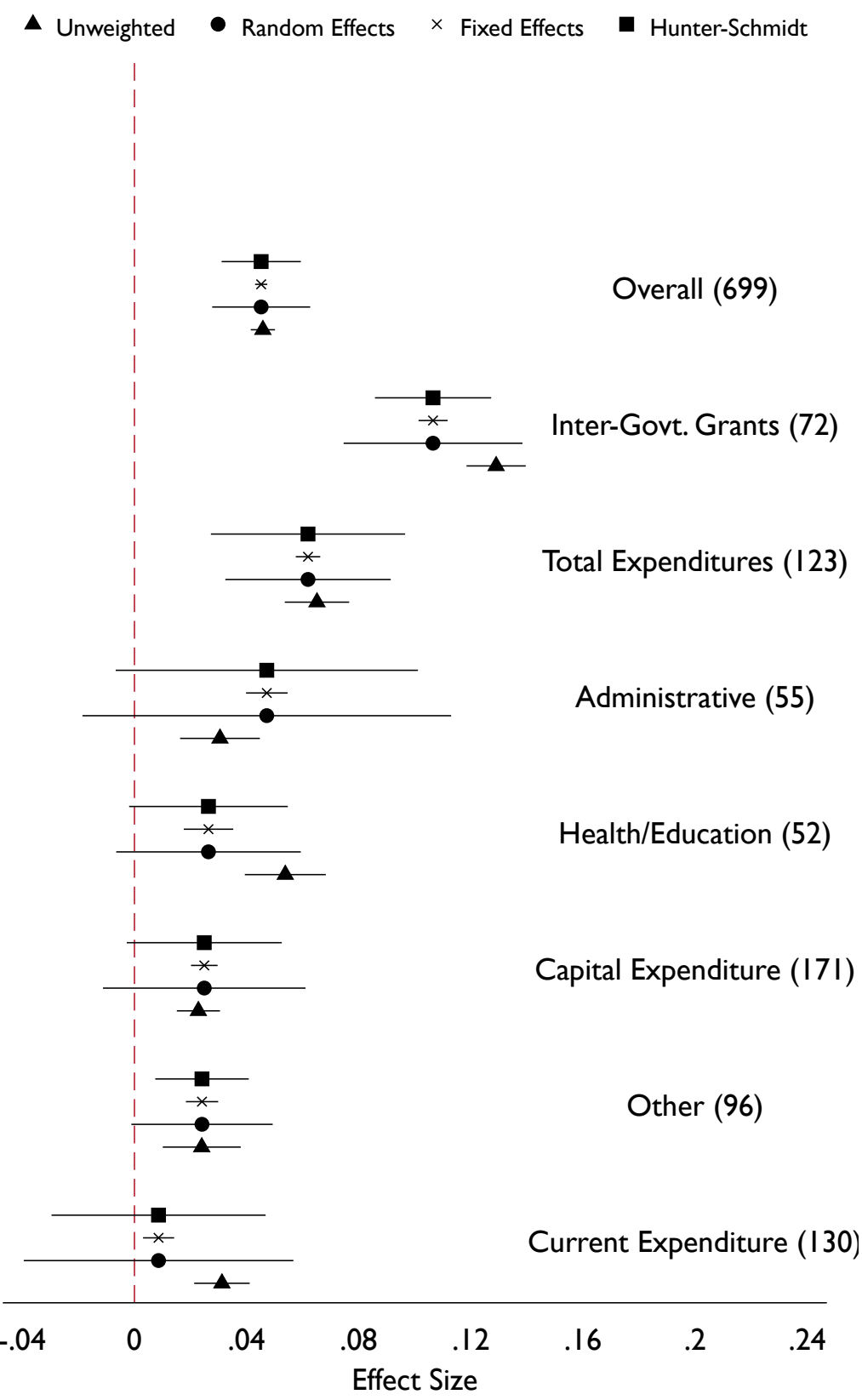

Figure 4: The political budget cycle effect: Expenditure disaggregation Notes: Study-model observations in parentheses. $95 \%$ confidence intervals reported. 
positive effect, Enkelmann and Leibrecht (2013) find virtually no effect, while Aidt and Mooney (2014) find a negative effect. For models that focus on education and health spending, a small, insignificant effect is evident. Since these two expenditures are often viewed as likely targets for fiscal manipulation, this finding is particularly interesting. The last calculated effect in Figure 4 is an "Other" category, which consists of fiscal variables, such as spending on agriculture, media, and defense. As with the other disaggregated categories, little evidence of a significant political budget cycle effect can be found.

\section{Explaining context through meta-regression}

The previous section reported clear evidence of a political budget cycle for fiscal surplus, expenditures, revenue, and debt. While calculating the effect of the partial correlation adds a measure of uncertainty to our estimates, it does not inform us as to how much a particular data-specific or methodological choice alters the magnitude of the budget cycle. Moreover, although calculated effects appear to vary greatly across the various disaggregations explored above, the findings did not account for the possibility that other confounding variables may be explaining some of these differences. To examine this I turn to meta-regression analysis (MRA). This approach attempts to explain between-study variance by regressing the partial correlation of model $j$ of study $i$ on so-called "moderator variables" — data characteristics, methodological choices, and author- or paper-specific characteristics:

$$
\begin{aligned}
\varepsilon_{i j}= & f(\text { fiscal variables }, \text { data characteristics, author } / \text { study characteristics }, \\
& \text { methodology, election variables, moderating variables })
\end{aligned}
$$

The regressors in Equation 4 can identify important contextual conditions in the literature (Stanley|2001). A significant positive (negative) coefficient indicates that the presence of the moderator 
variable tends to increase (reduce) the partial correlation, $\varepsilon_{i j}$, all else equal. While MRAs cannot identify the magnitude of the effect that a larger or smaller moderator variable has on the partial correlation, it does inform us as to the relative importance of the variable on the size of the effect reported in the literature. Statistical (and substantive) significance of a moderator variable suggests that it should be included in future studies of political budget cycles, since it appears to condition the relationship between elections and budgets. For variables measuring the characteristics of the model, study, or data, statistical significance in the MRA suggests that an analysis with that particular moderator variable is a relative outlier and should be generalized to the broader population with caution.

One drawback to MRAs is that considerable disagreement exists on which moderator variables to include. Multicollinearity and few degrees of freedom can be problematic, just as with standard regressions. Because of this, I am able to analyze only the three most important dependent variable categories: fiscal balance, expenditures, and revenues $8^{8}$ In addition to the different categories of the dependent variables analyzed in the previous section, I identified and coded 40 other candidate covariates that may contribute to differences among partial correlations. These are shown in Table 1. along with means, standard deviations, and a brief description.

Table 1: Candidate covariates that may explain differences in partial correlations

\begin{tabular}{|c|c|c|c|}
\hline Variable & Variable description & Mean & Std. dev. \\
\hline \multicolumn{4}{|l|}{ Expenditure variables } \\
\hline Total expenditures & $=1$ if dependent variable is total expenditures & 0.10 & 0.31 \\
\hline Inter-govt. grants & $=1$ if dependent variable is grants/transfers & 0.06 & 0.24 \\
\hline Capital expenditures & $=1$ if dependent variable is capital expenditures & 0.15 & 0.35 \\
\hline Current expenditures & $=1$ if dependent variable is current expenditures & 0.11 & 0.31 \\
\hline Administrative expen & $\mathrm{s}=1$ if dependent variable is administrative expenditures & 0.05 & 0.21 \\
\hline Education and health & $=1$ if dependent variable is health/education expenditures & 0.04 & 0.21 \\
\hline \multicolumn{4}{|l|}{ Revenue variables } \\
\hline Total revenue & $=1$ if dependent variable is total revenue & 0.05 & 0.23 \\
\hline Tax revenue & $=1$ if dependent variable is tax revenue & 0.14 & 0.34 \\
\hline \multicolumn{4}{|l|}{ Data characteristics } \\
\hline
\end{tabular}

\footnotetext{
${ }^{8}$ Debt has only 22 model-study observations and is excluded.
} 


\begin{tabular}{|c|c|c|c|}
\hline Standard error & Standard error of the partial correlation & 0.05 & 0.03 \\
\hline OECD & $=1$ if at least one country is in $\mathrm{OECD}$ & 0.68 & 0.47 \\
\hline Latin America & $=1$ if at least one country is in Latin America & 0.23 & 0.42 \\
\hline Asia & $=1$ if at least one country is in Asia & 0.17 & 0.38 \\
\hline Sub-Saharan Africa & $=1$ if at least one country is in Sub-Saharan Africa & 0.09 & 0.29 \\
\hline E. Europe and Fmr. USSR & $=1$ if at least one country is in E. Europe and Fmr. USSR & 0.14 & 0.34 \\
\hline Average year & Average year in sample & 1986.4 & 16.97 \\
\hline Quarterly aggregation & $=1$ if temporal aggregation is quarterly & 0.06 & 0.23 \\
\hline Monthly aggregation & $=1$ if temporal aggregation is monthly & 0.02 & 0.13 \\
\hline Single country & $=1$ if single-country study & 0.46 & 0.50 \\
\hline Municipal aggregation & $=1$ if election level is municipal & 0.21 & 0.40 \\
\hline State aggregation & $=1$ if election level is state/provincial & 0.17 & 0.37 \\
\hline \multicolumn{4}{|l|}{ Moderating variables } \\
\hline Democracy & $=1$ if model controls for democracy (dummy, level, or index) & 0.01 & 0.10 \\
\hline Coalition & $=1$ if model controls for coalition, $\mathrm{maj} / \mathrm{min}$ government & 0.06 & 0.23 \\
\hline Debt (control) & $=1$ if model controls for debt level or percent & 0.04 & 0.19 \\
\hline Deficit (control) & $=1$ if model controls for deficit level or percent & 0.03 & 0.17 \\
\hline Govt. expenditures & $=1$ if model controls for total government expenditures & 0.03 & 0.17 \\
\hline Govt. revenues & $=1$ if model controls for total government revenues & 0.06 & 0.24 \\
\hline Transfers (control) & $=1$ if model controls for inter-governmental transfers & 0.07 & 0.25 \\
\hline GDP & $=1$ if model controls for output, in levels & 0.61 & 0.49 \\
\hline GDP growth & $=1$ if model controls for output growth & 0.34 & 0.47 \\
\hline Ideology & $=1$ if model controls for government ideology (dummy or index) & 0.21 & 0.40 \\
\hline Inflation & $=1$ if model controls for inflation & 0.03 & 0.18 \\
\hline Presidential & $=1$ if model controls for presidential systems & 0.01 & 0.12 \\
\hline Proportional & $=1$ if model controls for PR system & 0.03 & 0.16 \\
\hline Unemployment & $=1$ if model controls for unemployment & 0.12 & 0.32 \\
\hline Win margin & $=1$ if model controls for margin of victory of past election & 0.14 & 0.35 \\
\hline \multicolumn{4}{|l|}{ Methodology } \\
\hline Unit fixed-effects & $=1$ if model has unit/regional fixed effects & 0.59 & 0.49 \\
\hline Lagged dep. var. & $=1$ if model includes lagged dependent variable/GMM & 0.80 & 0.40 \\
\hline OLS PCSE GLS & $=1$ if model uses OLS, panel-corrected std. errors or GLS & 0.14 & 0.35 \\
\hline \multicolumn{4}{|l|}{ Election variables } \\
\hline Election dummy & $=1$ if model uses simple dummy & 0.57 & 0.50 \\
\hline Elec. half-yr & $=1$ if model uses dummy with May-June cutoff & 0.09 & 0.29 \\
\hline Franzese & $=1$ if model uses Franzese (2000) method & 0.17 & 0.37 \\
\hline Election pre-determined & $=1$ if election variable is for fixed elections & 0.13 & 0.34 \\
\hline Election early & $=1$ if election variable is for elections called early & 0.12 & 0.32 \\
\hline Election $_{t+1}$ & $=1$ if model includes period after election & 0.10 & 0.30 \\
\hline Election $_{t-1}$ & $=1$ if model includes period before election & 0.19 & 0.40 \\
\hline \multicolumn{4}{|l|}{ Study characteristics } \\
\hline Total models & Total number of models per study & 79.12 & 94.48 \\
\hline Cites per year & Average article citations per year & 3.00 & 3.48 \\
\hline Impact factor & Journal's impact factor (2013) & 1.11 & 0.84 \\
\hline
\end{tabular}

Notes: $N=1176$ for 79 studies. Debt is excluded due to lack of observations. 
Based on the earlier findings as well as the previous literature, I expect a number of covariates to be particularly influential. Since there was substantial heterogeneity in estimated effects across the seven expenditure categories and three revenue categories, these are each included as dichotomous variables, with "other expenditures" and "other revenues" as the omitted category for each analysis. A number of data characteristics also may influence the results. The standard error of the calculated partial correlations is included to proxy for estimation precision (Stanley and Doucouliagos 2012). I also include regional dummies since some regions may be more susceptible to political budget cycles than others, as cross-national analyses of recently democratic countries in Latin America (Barberia and Avelino 2011), and elsewhere (Brender and Drazen 2005) have shown. In addition, since the estimated effect could be influenced by temporal aggregation and the governing level at which elections were held, these, too, are entered. While previous authors have investigated how temporal aggregation may affect the likelihood of observing political budget cycles within a single dataset (Streb et al 2012, Klomp and De Haan|2013b), a MRA offers a more comprehensive approach as to how aggregation may influence the sizes and significances of political budget cycles.

I include 15 moderating variables that may condition political budget cycles. Each variable is a dichotomous indicator equal to one if the study in question included that variable. When entered into a MRA, a significant coefficient suggests that this variable may have an important conditional relationship with political budget cycles. Democracy is added with the expectation that including democracy in a regression will reduce the sizes of the partial correlations. Coalition governments are controlled for since they may affect political budget cycles (Hanusch 2012). A variety of fiscal controls, such as debt and expenditures, are entered since they are common in most analyses of the political budget cycle phenomenon. I control for whether economic conditions, such as GDP and unemployment, are held constant. I also include variables for presidential and proportional systems in addition to the win margin of the victorious candidate or party.

A variety of dichotomous variables are entered to account for the methodology used in the 
analysis. I include a dichotomous variable equal to one if the model contained unit fixed-effects. I also include a variable controlling for whether or not a lagged dependent variable was entered in the model, as well as if a simple OLS or a GLS model was estimated.

Since the election indicator is the key independent variable of interest, I explore how differences in coding affect political budget cycles. Three variables account for the most common types seen in the literature. The first, Election dummy, takes on a value of one if the election variable also takes on a value of one in the election period. Elec. half-yr. accounts for studies that establish a half-year cutoff for which the dummy variable equals one in the year of the election if it is held after May or June, or equals one in the year before the election if the election is held prior to May or June. Last, some studies adopt the technique attributed to Franzese (2000), which enters a variable equal to $\frac{M}{12}$ in the election year (where M equals the month of the election), and $1-\frac{M}{12}$ in the year before the election, thus weighting the election-year indicator based on the month in which the election is held. I also account for whether the study controlled for the period before an election, Election $_{t-1}$, as well as the period after the election, Election $_{t+1}$.

MRAs can also control for a variety of study characteristics that may proxy quality. To investigate how this may affect the size of the partial correlations, I include the total number of models in a given study, the average number of citations per year an article has received, and the 2013 impact factor of the journal in which the article was published. I expect that, especially if any form of publication bias exists, studies with more citations or published in journals with high impact factors will have stronger evidence for political budget cycles.

\section{Results}

Results from the MRA for expenditures are shown in Table 2. Model 1 uses the random-effects specification described earlier by regressing the calculated partial correlations on the list of charac- 
teristics that could be influencing the estimated political budget cycle effect. Model 2 assumes no between-study variance using the fixed-effects specification, so its large proportion of statistically significant results should be interpreted with caution. Both Models 1 and 2 are weighted by the number of study observations. In addition to a frequentist approach, Model 3 uses a data-driven approach to see which moderator variables are important for explaining differences in the partial correlations through Bayesian model averaging (BMA). This strategy has been used in previous meta-analyses (Iršová and Havránek 2013; Moeltner and Woodward 2009), and is useful for a number of reasons. First, it can be used to find the model that explains more variation than all others the algorithm covers. Second, we obtain posterior inclusion probabilities for each covariate- or the likelihood that a given variable enters the final model. By convention, variables with posterior inclusion probabilities exceeding 0.10 are deemed important; these are shown in italics in Model 3. Third, the resulting model produces a posterior mean and standard deviation, which are analogous to a coefficient and standard error in a frequentist model. Finally, by searching for the model that maximizes explained variance by including or excluding candidate covariates, BMA offers an ideal tradeoff between a parsimonious (yet potentially underspecified) model, and one that—by including all covariates-is as comprehensive as possible, yet potentially over-saturated and full of extraneous variables (Aguinis et al 2011). Model 3 is estimated using a Markov chain Monte Carlo approach to select candidate models using the Metropolis-Hastings algorithm (Feldkircher and Zeugner 2009).9 Last, Model 4 re-estimates a random-effects model using only variables that had posterior inclusion probabilities of 0.10 or larger in Model 3.

Table 2: Explaining differences in partial correlations of expenditures

$\begin{array}{cccc}\text { Model 1 } & \text { Model 2 } & \text { Model 3 } & \text { Model 4 } \\ \text { RE } & \text { FE } & \text { BMA } & \text { RE }\end{array}$

\footnotetext{
${ }^{9}$ There are two important priors to specify. The first is how many variables should be included in the "true" model. Since I have no prior expectation as to how many variables should be included, I chose a diffuse beta-binomial model prior (Ley and Steel 2009). The second set of priors concern the coefficients. I chose uninformed coefficient priors (Fernandez et al 2001), although the findings remain robust to alternative priors, as detailed in the Supplemental Materials.
} 


\begin{tabular}{|c|c|c|c|c|c|}
\hline \multicolumn{6}{|l|}{ Data characteristics } \\
\hline Standard error & $-3.372^{* * *}(1.060)$ & $-3.372^{* * *}(0.396)$ & $1.100(0.077)$ & $0.668^{*}$ & $(0.392)$ \\
\hline OECD & $0.811^{* *}(0.378)$ & $0.811^{* * *}(0.140)$ & $0.002(0.008)$ & & \\
\hline Latin America & $0.011 \quad(0.034)$ & $0.011 \quad(0.010)$ & $0.001(0.008)$ & & \\
\hline Asia & $-0.015(0.031)$ & $-0.015 \quad(0.009)$ & $-0.021(0.031)$ & -0.012 & $(0.022)$ \\
\hline Sub-Saharan Africa & $-0.001 \quad(0.041)$ & $-0.001 \quad(0.012)$ & $0.038(0.048)$ & & \\
\hline E. Europe and Fmr. USSR & $0.061 \quad(0.043)$ & $0.061^{* * *}(0.017)$ & $-0.002(0.009)$ & 0.022 & $(0.029)$ \\
\hline Average year & $-0.051^{* *}(0.021)$ & $-0.051^{* * *}(0.009)$ & $0.000(0.000)$ & 0.001 & $(0.0004)$ \\
\hline Quarterly aggregation & $0.002^{* * *}(0.001)$ & $0.002^{* * *}(0.000)$ & $0.001(0.009)$ & & \\
\hline Monthly aggregation & $0.111^{*}(0.060)$ & $0.111^{* * *}(0.029)$ & $0.001(0.008)$ & & \\
\hline Single country & $-0.120 \quad(0.087)$ & $-0.120^{* * *}(0.029)$ & $0.002(0.008)$ & & \\
\hline Municipal aggregation & $0.000 \quad(0.042)$ & $0.000 \quad(0.009)$ & $0.016(0.022)$ & $0.039^{* *}$ & $(0.019)$ \\
\hline State aggregation & $0.052^{* *}(0.024)$ & $0.052^{* * *}(0.005)$ & $-0.028(0.031)$ & $0.057^{* *}$ & $(0.023)$ \\
\hline \multicolumn{6}{|l|}{ Moderating variables } \\
\hline Democracy & $0.042(0.029)$ & $0.042^{* * *}(0.009)$ & $0.014(0.036)$ & 0.062 & $(1.466)$ \\
\hline Coalition & $0.076 \quad(0.072)$ & $0.076^{* * *}(0.025)$ & $0.002(0.009)$ & & \\
\hline Debt & $-0.078^{* *}(0.037)$ & $-0.078^{* * *}(0.009)$ & $0.002(0.010)$ & & \\
\hline Deficits & $0.055 \quad(0.033)$ & $0.055^{* * *}(0.016)$ & $0.001(0.006)$ & & \\
\hline GDP & $-0.011 \quad(0.044)$ & $-0.011 \quad(0.011)$ & $0.000(0.002)$ & & \\
\hline GDP growth & $0.026 \quad(0.018)$ & $0.026^{* * *}(0.005)$ & $-0.000(0.002)$ & & \\
\hline Expenditures (control) & $-0.073^{* *}(0.036)$ & $-0.073^{* * *}(0.012)$ & $-0.036(0.039)$ & $-0.047^{*}$ & $(0.026)$ \\
\hline Ideology & $-0.061^{* *}(0.027)$ & $-0.061^{* * *}(0.006)$ & $0.001(0.006)$ & & \\
\hline Inflation & $0.052^{* *}(0.021)$ & $0.052^{* * *}(0.005)$ & $0.002(0.010)$ & & \\
\hline Presidential & $0.001 \quad(0.053)$ & $0.001 \quad(0.011)$ & $0.005(0.020)$ & & \\
\hline Proportional & $-0.005 \quad(0.059)$ & $-0.005 \quad(0.022)$ & $-0.000(0.008)$ & & \\
\hline Revenues (control) & $0.022(0.062)$ & $0.022 \quad(0.021)$ & $0.079(0.026)$ & $0.030^{*}$ & $(0.022)$ \\
\hline Transfers (control) & $0.035 \quad(0.023)$ & $0.035^{* * *}(0.006)$ & $0.008(0.019)$ & $0.037^{*}$ & $(0.021)$ \\
\hline Unemployment & $0.017 \quad(0.033)$ & $0.017^{* * *}(0.006)$ & $0.038(0.024)$ & $0.026^{*}$ & $(0.015)$ \\
\hline Win margin & $0.001 \quad(0.022)$ & $0.001 \quad(0.008)$ & $0.000(0.004)$ & & \\
\hline \multicolumn{6}{|l|}{ Methodology } \\
\hline Unit fixed-effects & $0.028 \quad(0.027)$ & $0.028^{* * *}(0.008)$ & $-0.000(0.003)$ & & \\
\hline Lagged dep. var. & $-0.036 \quad(0.049)$ & $-0.036^{* * *}(0.005)$ & $-0.094(0.016)$ & -0.0108 & $(0.026)$ \\
\hline OLS PCSE GLS & $-0.015 \quad(0.022)$ & $-0.015^{* *}(0.006)$ & $0.013(0.022)$ & 0.001 & $(0.022)$ \\
\hline \multicolumn{6}{|l|}{ Election variables } \\
\hline Election dummy & $-0.050 \quad(0.055)$ & $-0.050^{* * *}(0.008)$ & $-0.010(0.018)$ & -0.026 & $(0.019)$ \\
\hline Franzese & $-0.031 \quad(0.027)$ & $-0.031^{* * *}(0.010)$ & $0.000(0.002)$ & & \\
\hline Elec. half-yr & $0.042(0.028)$ & $0.042^{* * *}(0.010)$ & $0.005(0.015)$ & 0.010 & $(0.425)$ \\
\hline Election pre-determined & $-0.067 \quad(0.047)$ & $-0.067^{* * *}(0.015)$ & $-0.008(0.017)$ & $-0.031^{* *}$ & $(0.015)$ \\
\hline Election early & $-0.029(0.025)$ & $-0.029^{* * *}(0.010)$ & $0.000(0.004)$ & & \\
\hline Election $_{t+1}$ & $0.008 \quad(0.025)$ & $0.008 \quad(0.010)$ & $0.010(0.022)$ & 0.040 & $(0.027)$ \\
\hline Election $_{t-1}$ & $0.104^{* * *}(0.033)$ & $0.104^{* * *}(0.012)$ & $-0.000(0.002)$ & & \\
\hline \multicolumn{6}{|l|}{ Study characteristics } \\
\hline Total models & $-0.031 \quad(0.023)$ & $-0.031^{* * *}(0.005)$ & $-0.000(0.000)$ & & \\
\hline Cites per year & $0.000 \quad(0.000)$ & $0.000^{*}(0.000)$ & $0.005(0.004)$ & $0.006^{*}$ & $(0.003)$ \\
\hline Impact factor & $0.004 \quad(0.004)$ & $0.004^{* * *}(0.001)$ & $0.006(0.010)$ & $-0.028^{* * *}$ & ${ }^{*}(0.010)$ \\
\hline
\end{tabular}




\begin{tabular}{lccccccc} 
Administrative expenditures & -0.003 & $(0.017)$ & $-0.003(0.006)$ & $-0.000(0.003)$ & & \\
Capital expenditures & 0.015 & $(0.026)$ & $0.015^{* * *}(0.005)$ & $-0.000(0.002)$ & & \\
Current expenditures & -0.020 & $(0.027)$ & $-0.020^{* * *}(0.005)$ & $0.002(0.008)$ & & \\
Inter-govt. grants & -0.028 & $(0.028)$ & $-0.028(0.005)$ & $-0.077(0.022)$ & $0.112^{* * *}$ & $(0.024)$ \\
Education and health exp. & $0.068^{* *}$ & $(0.032)$ & $0.068^{* * *}(0.008)$ & $0.000(0.002)$ & & \\
Total expenditures & -0.005 & $(0.028)$ & $-0.005(0.006)$ & $0.016(0.020)$ & 0.034 & $(0.027)$ \\
Constant & $0.016(0.031)$ & $0.016^{* * *}(0.005)$ & & $-1.209(0.790)$ \\
$\mathrm{R}^{2}$ & 0.32 & & & & 0.30 \\
$\mathrm{I}^{2}$ & 0.88 & & & & 0.89 \\
\hline
\end{tabular}

Notes: Dependent variable is the partial correlation of study-model $i j$. Coefficients with standard errors in parentheses for Models 1, 2, and 4. Posterior means with posterior standard deviations in parentheses for Model 3. * $p<0.10, * * p<0.05, * * * p<0.01$ for frequentist models. Estimates in italics in Model 3 indicate a posterior inclusion probability greater than 0.10 .699 model-study observations for 61 studies for all models, with a total sample size of $1,027,186$.

\subsection{Data characteristics}

In a MRA, characteristics of the data often influence the sizes of the partial correlations. The variable that accounts for the standard error of the partial correlation has a large negative effect in Models 1 and 2 and a somewhat smaller positive effect in Models 3 and 4. These mixed yet strong effects are not surprising given that the funnel plot in Figure 1 suggested that estimates with less precision (larger standard errors) tend to produce large positive or negative partial correlations. In other words, studies with less precision find evidence of a substantial political budget cycle effect, but they also are likely to report evidence that expenditures decline around elections. With the exception of the OECD, the five regional dummies generally reveal no statistically significant effects on the partial correlation. This OECD finding is surprising; after controlling for other factors, a substantial relationship exists between elections and expenditures in OECD countries. The same is true for studies examining countries of Eastern Europe and the former Soviet Union, though the effect is smaller. In contrast, Asian countries appear to be less susceptible to political budget cycles. The average year covered by the sample appears to have some influence on the partial correlation, though this effect is negative in Models 1 and 2 and positive and near-zero in 
Models 3 and 4.

Characteristics relating to the temporal aggregation and level of analysis also appear to affect the sizes of political budget cycles. Relative to studies using annual data, those using quarterly and monthly observations tend to find more positive partial correlations, all else equal. This suggests that temporally disaggregated data are better at detecting political budget cycles. Studies of one country only appear to produce results similar to studies examining multiple countries. In contrast, the level of government at which an election is held appears to be driving some of the differences in partial correlations; studies of municipal elections are positive (albeit near-zero for Models 1 and 2) across all models. Studies at the state or provincial level find even stronger political budget cycle effects, with the positive coefficient remaining robust across all estimates except Model 3. All of this evidence suggests that sub-national political budget cycles tend to be stronger than national ones.

\subsection{Moderating variables}

The significance of some of the moderating variables in Table 2 suggests that important conditional relationships may play important roles in the political budget cycle literature. The consolidation and duration of democracy has been theorized to lead to smaller political budget cycles (Brender

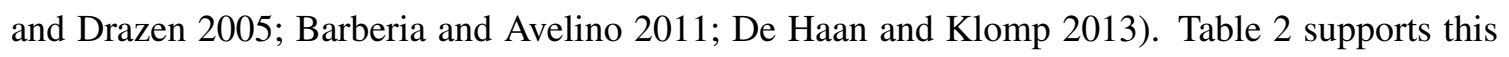
finding; studies that control for the effects of democracy tend to produce a larger partial correlation, all else equal. Thus, democracy appears to be a key factor in explaining the relationship between elections and public spending. Controlling for coalition goverments does not have a statistically significant effect, which suggests that coalition and non-coalition governments are equally likely to create political budget cycles. While accounting for debt tends to reduce the partial correlations, deficits appear to be unrelated to the political budget cycle effect. Neither GDP in levels nor GDP 
growth appears to influence the size of the partial correlations, suggesting that both advanced and developing economies are equally susceptible to political budget cycles. In contrast, controlling for expenditures appears to be an important predictor of the size of the partial correlations. Controlling for expenditures leads to smaller correlations, as does political ideology. On the other hand, accounting for inflation appears to increase the size of the partial correlations. Neither presidential nor proportional systems, or win margins, appear to have any moderating effect on political budget cycles. This is consistent with the mixed evidence on the effect that parliamentary and majoritarian systems have on political budget cycles (Persson and Tabellini 2005; Streb et al 2009; Klomp and De Haan 2013b). Last, controlling for revenues, transfers and unemployment appears to be important, as evidenced by the positive coefficients in Table 2 .

\subsection{Methodology}

A number of variables that account for the methodology used in the study appear to influence the magnitude of the estimated partial correlations. The unit fixed effects variable is statistically significant only in Model 2, which suggests that many of the findings reported in the literature do not hinge on choosing between fixed- or random-effects models. In contrast, the variable for a lagged dependent variable is negative and has a large posterior inclusion probability in Model 3 (and therefore is entered in Model 4). This result indicates that models entering a lagged dependent variable are likely to have smaller partial correlations than those that do not, all else equal. Models that address dynamics (either by including a lagged dependent variable, error correction model, or utilizing a generalized method of moments model) are much better reflections of the data-generation process, since fiscal variables tend to exhibit strong autoregressive tendencies. Given this finding, models that do not address dynamic issues appear to be overstating political budget cycles, since they inflate the size of the election year coefficient. Interestingly, studies that used simple estimation methods, such as OLS, have tended to understate the amplitudes of political budget cycles, 
although these negative coefficients become positive in Models 3 and 4.

\subsection{Election variables}

Since many studies investigate robustness by varying the electoral "window" (e.g., Streb et al 2012), or the coding of the election variables, the results in Table 2 are of particular importance. I find evidence that coding the election as a simple dummy variable in the year of the election tends to lead to smaller partial correlations. In contrast, fine-grained approaches, such as coding with a half-year cutoff point, tend to lead to larger partial correlations. This result suggests that, all else equal, political budget cycles may be influenced by how the election timing is controlled for, although note that the method used by Franzese appears not to affect the size of the partial correlations. Moreover, the significance of the pre-determined election variable suggests that differences exist between fixed and non-fixed election dates. This finding is in line with the large body of literature on how elections are not always exogenous to the public budget process (Shi and Svensson 2006). Last, pre- and post- election dummy variables often are included in studies of political budget cycles. I find that studies that enter such control variables tend to find more positive partial correlations. Accounting for pre- and post-election periods thus seems to be important in studying electoral effects on public budgets. Taken together, these results suggest that political budget cycles are sensitive to the coding of elections (more fine-grained indicators are better at uncovering the underlying effect) as well as varying the electoral window.

\subsection{Study characteristics}

Study characteristics appear to have only minor effects on political budget cycles. The total number of models appear to be unrelated to the partial correlations. Both the number of study citations per year and the journal's impact factor are positively related to the partial correlations in Models 1, 2, 
and 3, although this effect is substantively very small. However, the fact that both variables enter into Model 4 (i.e., had a high posterior inclusion probability using Bayesian model averaging) suggests that they are important predictors of the partial correlations.

\subsection{Fiscal variables}

Out of the six fiscal variables in Table 2, only intergovernmental grants, education and health spending, and total expenditures appear to explain differences among the partial correlations. Although nearly all fiscal variables are statistically significant in Model 2, the result should be interpreted with caution, since the large $I^{2}$ value in Models 1 and 4 suggest that the random-effects model is preferable because of the large share of variance explained by study heterogeneity. Model 4 indicates that intergovernmental grants are positively associated with the partial correlations, as are total expenditures, although the latter is not statistically significant. That a highly aggregated category such as total expenditures produces some of the strongest evidence for political budget cycles runs contrary to the theoretical arguments about how disaggregated categories of spending (e.g., administrative, capital, or current expenditures) should be the most likely to reveal a political budget cycle effect (Vergne 2009; Brender and Drazen 2013).

\subsection{Revenues}

The previous section examined evidence of political budget cycles in public spending in the context of a MRA. Do similar patterns emerge in public revenues? Table 3 uses the same estimation strategy as before, but examines the 243 studies in which revenue was the dependent variable. Interestingly, neither the impact factor nor the standard error of the partial correlation produced posterior inclusion probabilities large enough to merit inclusion in Model 8. This result suggests that publication bias may be less of a problem for studies that examine revenues rather than expen- 
ditures. While temporal aggregation and the level of analysis influence governmental expenditures, only quarterly aggregation appears to be an important predictor for revenues (albeit not statistically significant) in Model 8. All else equal, studies using quarterly data tend to find that revenues increase prior to Election Day. The only regional dummies that reveal a posterior inclusion probability exceeding 0.10 are studies examining the countries of Eastern Europe and the former Soviet Union. Since the coefficient is positive, it appears that both revenues and expenditures increase in these regions during elections, all else equal.

Unlike expenditures, few moderating variables have significant effects on the partial correlations for revenues. GDP growth is positively signed in Model 8, suggesting that it may be necessary to include that variable in studies of revenue cycles. Controlling for revenue and unemployment, both of which have negative signs (i.e., including these variables tends to intensify the decline in revenues during elections), may also be important. The finding that unemployment matters is similar to the findings for expenditures in Table 2. Taken together, these results suggest that incumbents manipulate budget balances—either by increasing expenditures or reducing revenues—only when the unemployment rate is high.

The results for the methodology and election variables in Table 3 have some similarities and some differences with respect to the expenditure results. For both, I find that dynamics are particularly important to incorporate into models of political budget cycles by entering a lagged dependent variable. However, less fine-grained election indicators, such as simple election year dummies, are associated with more negative partial correlations for both the revenue and expenditure results. For revenues, the negative coefficient indicates that revenues are reduced more around elections when a coarse electoral window is defined. Last, in both models of revenues and expenditures, differences seem to exist between elections that are fixed and those that are called early.

A few study characteristics seem to affect the size of the partial correlations for revenues. Both 
Table 3: Explaining differences in partial correlations of revenues

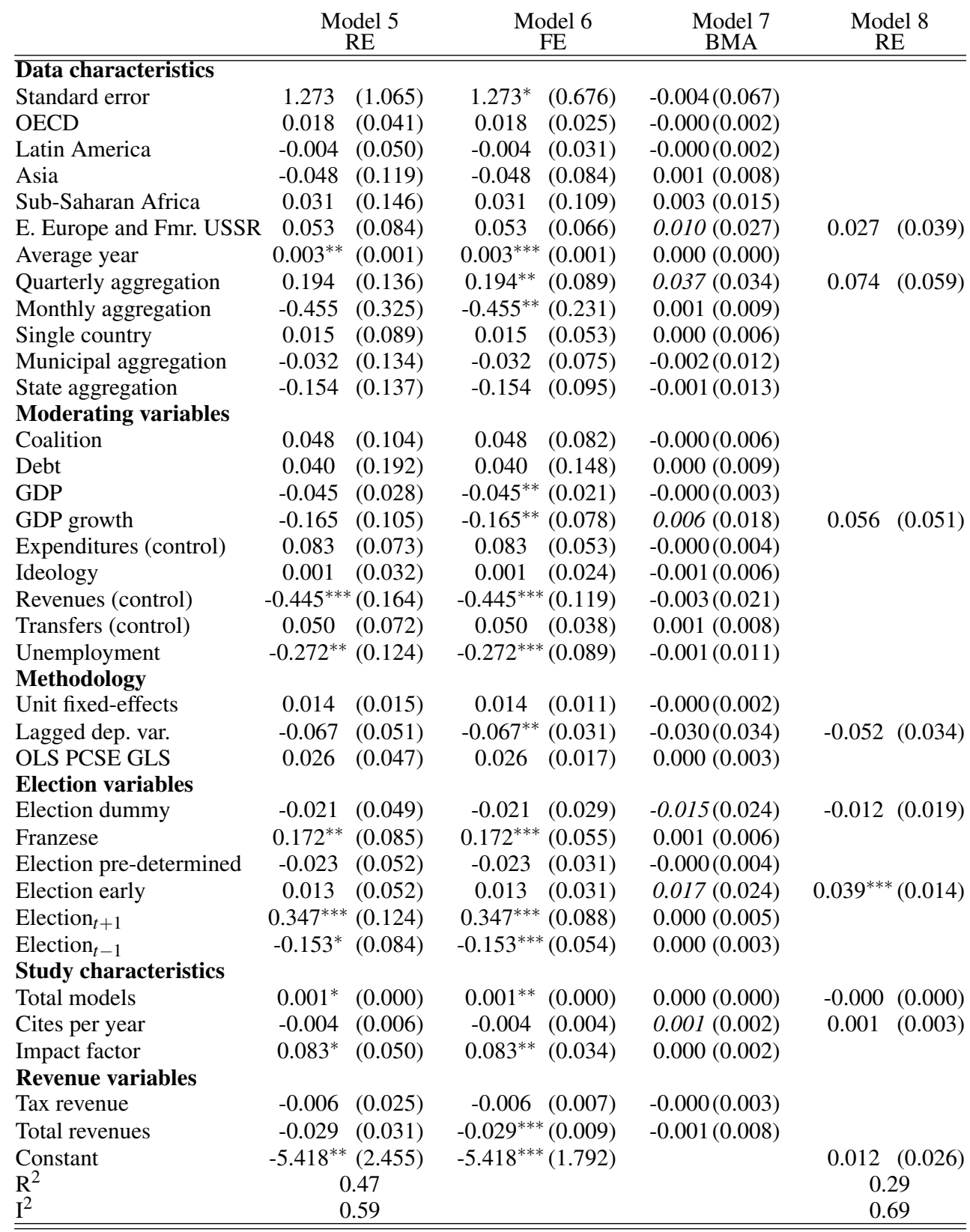

Notes: Dependent variable is the partial correlation of study-model $i j$. Coefficients with standard errors in parentheses for Models 5, 6, and 8. Posterior means with posterior standard deviations in parentheses for Model 7. * $p<0.10, * *$ $p<0.05$, *** $p<0.01$ for frequentist models. Estimates in italics in Model 7 indicate a posterior inclusion probability greater than 0.10. 243 model-study observations for 23 studies for all models, with a total sample size of 245,404. Due to the smaller number of observations, the variables on democracy, presidential, proportional, win margin, deficit, inflation, election half-year were excluded. 
the total number of models in a study and the average number of citations received per year largely are significant across all models, although the magnitude of this effect is small and switches signs when moving to Model 8. The journal's impact factor is positive and significant in Models 5 and 6, indicating that higher quality journals (according to impact factor) often find that revenues increase during elections. Last, in contrast to public spending, I find no evidence of any systematic differences across the types of dependent variable used in the analysis. These results suggest that, after accounting for other factors, political budget cycles are equally likely in all revenue categories.

\subsection{Fiscal balance}

As shown in Figure 2, studies specifying fiscal surplus as a dependent variable tended to find some of the strongest evidence of political budget cycles. To see that result remains robust to the addition of study and data characteristics, Table 4 shows the results from the 234 such studies in the sample that use fiscal surplus as a dependent variable. I find few differences across regions, and, moreover, temporal aggregation does not appear to influence the results. In contrast, while single-country analyses tend to find evidence of a "reverse" political budget cycle (the positive coefficent indicates that fiscal surpluses rise during elections), Table 4 suggests that municipalities tend to run budget deficits during elections.

Although a number of moderating variables are statistically significant across Models 9 and 10, none had high enough posterior inclusion probabilities in Model 11 to be entered into Model 12. Nor did any of the election variables or study characteristics. In contrast, the coefficient on lagged dependent variables is positive and statistically significant across all models, indicating that studies accounting for dynamics find evidence of less deficit spending during elections. All of this suggests that relatively few differences across studies help explain the underlying political budget cycle effect of fiscal surpluses. 
Table 4: Explaining differences in partial correlations of fiscal balance

\begin{tabular}{|c|c|c|c|c|}
\hline & $\begin{array}{c}\text { Model } 9 \\
\text { RE }\end{array}$ & $\begin{array}{c}\text { Model } 10 \\
\text { FE }\end{array}$ & $\begin{array}{l}\text { Model } 11 \\
\text { BMA }\end{array}$ & $\begin{array}{c}\text { Model } 12 \\
\text { RE }\end{array}$ \\
\hline \multicolumn{5}{|l|}{ Data characteristics } \\
\hline Standard error & $-1.146^{* * *}(0.381)$ & $-1.146^{* * *}(0.367)$ & $-0.005(0.057)$ & \\
\hline OECD & $0.000 \quad(0.009)$ & $0.000 \quad(0.008)$ & $-0.000(0.001)$ & \\
\hline Latin America & $0.001 \quad(0.010)$ & $0.001 \quad(0.009)$ & $-0.000(0.001)$ & \\
\hline Asia & $-0.080^{* * *}(0.026)$ & $-0.080^{* * *}(0.025)$ & $0.000(0.001)$ & \\
\hline Sub-Saharan Africa & $0.006 \quad(0.024)$ & $0.006 \quad(0.023)$ & $0.000(0.001)$ & \\
\hline E. Europe and Fmr. USSR & $0.045^{* *}(0.021)$ & $0.045^{* *}(0.020)$ & $0.000(0.001)$ & \\
\hline Average year & $-0.001^{* *}(0.000)$ & $-0.001^{* *}(0.000)$ & $0.000(0.000)$ & \\
\hline Quarterly aggregation & $-0.021 \quad(0.014)$ & $-0.021 \quad(0.013)$ & $0.000(0.001)$ & \\
\hline Monthly aggregation & $-0.140^{*}(0.081)$ & $-0.140^{*}(0.075)$ & $-0.000(0.008)$ & \\
\hline Single country & $0.176^{* * *}(0.038)$ & $0.176^{* * *}(0.037)$ & $0.024(0.048)$ & $0.068^{* *}(0.029)$ \\
\hline Municipal aggregation & $-0.311^{* * *}(0.044)$ & $-0.311^{* * *}(0.042)$ & $-0.041(0.077)$ & $-0.027 \quad(0.041)$ \\
\hline State aggregation & $-0.121^{* *}(0.049)$ & $-0.121^{* * *}(0.047)$ & $0.070(0.073)$ & $0.012 \quad(0.033)$ \\
\hline \multicolumn{5}{|l|}{ Moderating variables } \\
\hline Democracy & $0.087^{*} \quad(0.051)$ & $0.087^{*} \quad(0.048)$ & $0.000(0.007)$ & \\
\hline Coalition & $-0.056(0.044)$ & $-0.056(0.043)$ & $-0.001(0.009)$ & \\
\hline Debt & $-0.005 \quad(0.020)$ & $-0.005 \quad(0.020)$ & $-0.000(0.005)$ & \\
\hline GDP & $-0.001 \quad(0.017)$ & $-0.001 \quad(0.017)$ & $-0.000(0.002)$ & \\
\hline GDP growth & $0.030^{* *}(0.012)$ & $0.030^{* *}(0.012)$ & $0.000(0.002)$ & \\
\hline Ideology & $0.091^{* * *}(0.018)$ & $0.091^{* * *}(0.017)$ & $0.004(0.015)$ & \\
\hline Inflation & $0.020 \quad(0.020)$ & $0.020 \quad(0.018)$ & $-0.001(0.008)$ & \\
\hline Presidential & $-0.035 \quad(0.038)$ & $-0.035 \quad(0.035)$ & $-0.000(0.006)$ & \\
\hline Revenues (control) & $-0.041^{*}(0.023)$ & $-0.041^{*}(0.022)$ & $-0.001(0.009)$ & \\
\hline Transfers (control) & $0.088^{* * *}(0.027)$ & $0.088^{* * *}(0.020)$ & $0.000(0.004)$ & \\
\hline Unemployment & $-0.057^{*}(0.031)$ & $-0.057^{*}(0.029)$ & $-0.006(0.025)$ & \\
\hline Win margin & $0.095^{* *}(0.041)$ & $0.095^{* *}(0.040)$ & $0.001(0.011)$ & \\
\hline \multicolumn{5}{|l|}{ Methodology } \\
\hline Unit fixed-effects & $0.007 \quad(0.017)$ & $0.007 \quad(0.016)$ & $-0.000(0.002)$ & \\
\hline Lagged dep. var. & $0.140^{* * *}(0.038)$ & $0.140^{* * *}(0.036)$ & $0.220(0.094)$ & $0.192^{* * *}(0.025)$ \\
\hline OLS PCSE GLS & $0.009 \quad(0.021)$ & $0.009 \quad(0.019)$ & $-0.001(0.005)$ & \\
\hline \multicolumn{5}{|l|}{ Election variables } \\
\hline Election dummy & $0.018^{*}(0.009)$ & $0.018^{* *}(0.008)$ & $-0.000(0.001)$ & \\
\hline Franzese & $-0.017 \quad(0.021)$ & $-0.017 \quad(0.020)$ & $-0.000(0.003)$ & \\
\hline Elec. half-yr & $-0.054^{* *}(0.023)$ & $-0.054^{* * *}(0.020)$ & $-0.000(0.005)$ & \\
\hline Election pre-determined & $0.070^{* * *}(0.020)$ & $0.070^{* * *}(0.018)$ & $0.002(0.011)$ & \\
\hline Election early & $0.022 \quad(0.020)$ & $0.022 \quad(0.018)$ & $-0.000(0.001)$ & \\
\hline Election $_{t+1}$ & $0.016 \quad(0.010)$ & $0.016^{*}(0.009)$ & $0.000(0.002)$ & \\
\hline Election $_{t-1}$ & $-0.002 \quad(0.013)$ & $-0.002 \quad(0.011)$ & $-0.000(0.001)$ & \\
\hline \multicolumn{5}{|l|}{ Study characteristics } \\
\hline Total models & $0.000 \quad(0.000)$ & $0.000 \quad(0.000)$ & $0.000(0.000)$ & \\
\hline Cites per year & $0.003^{* *}(0.001)$ & $0.003^{* * *}(0.001)$ & $0.000(0.000)$ & \\
\hline Impact factor & $0.002(0.011)$ & $0.002 \quad(0.010)$ & $-0.000(0.001)$ & \\
\hline Constant & $1.640^{*}(0.970)$ & $1.640^{*}(0.872)$ & & $-0.271^{* * *}(0.025)$ \\
\hline $\mathrm{R}^{2}$ & 0.89 & & & 0.29 \\
\hline $\mathrm{I}^{2}$ & 0.11 & & & 0.46 \\
\hline
\end{tabular}

Notes: Dependent variable is the partial correlation of study-model $i j$. Coefficients with standard errors in parentheses for Models 9, 10, and 12. Posterior means with posterior standard deviations in parentheses for Model 11. * $p<0.10$, ** $p<0.05,{ }^{* * *} p<0.01$ for frequentist models. Estimates in italics in Model 11 indicate a posterior inclusion probability greater than 0.10. 234 model-study observations for 39 studies for all models, with a total sample size of 201,888. Due to the smaller number of observations, the variables on expenditures (control), proportional, and deficit were excluded. 


\section{Discussion}

The findings in this paper have substantial implications for the political budget cycle literature. I emphasize a number of key points. First, I disaggregated the dependent variables common in these studies into four categories: expenditures, revenues, fiscal balance, and public debt, as well as a number of sub-categories. As expected, I find that expenditures and debt increase during elections, while revenues and fiscal surpluses decline. Based on funnel plots of the weighted partial correlations, as well as the absence of significant variables in the meta-regression analysis, it appears that public budget balance shows the most consistent evidence of a robust political budget cycle; governments consistently run larger deficits around elections.

Using meta-regression analysis, I find that political budget cycles may be more likely to occur in some expenditure categories than in others. Although many scholars have theorized that highly disaggregated "visible" spending categories are most likely to be manipulated, I find instead that total expenditures rise during elections. This evidence suggests that incumbents may be manipulating multiple budgetary line items at once rather than increasing spending in a single category. I also find that grants between tiers of government show some of the strongest political budget cycle effects.

I also find that aggregating data annually rather than quarterly tends to reduce the sizes of observed political budget cycles for expenditures, but less so for revenues and fiscal surpluses. This finding complements existing work on how raising the level of temporal aggregation may hide an important dimension of variation (Streb et al 2012; Klomp and De Haan 2013b). In addition, this study was the first to test how the level of government at which elections are held affects the evidence for political budget cycles. Municipal- and national-level elections appear to be associated with increases in public spending and budget deficits. In contrast, election-based cycles in revenues are not more prevalent at sub-national levels of government. 
The results indicate that political budget cycles are present in a variety of contexts. Continental dummies largely are inconsequential throughout much of the meta-regression analysis, and factors thought previously to condition the budget cycle, such as electoral competitiveness and government ideology, have negligible effects in the MRA reported herein. Neither were most methodological choices, or decisions about coding the electoral window. Several important exceptions to that conclusion emerged, however. First, it appears that specifying dynamics is important; the significance of a lagged dependent variable in the meta-regression results suggests the need to account for budgetary incrementalism. Second, democracy and economic development appear to be two important moderating variables that have conditioning effects on political budget cycles, as evidenced by the significant coefficients in the meta-regression, and by previous studies (e.g., Brender and Drazen 2005). In addition, governmental revenues and expenditures, when entered as control variables, tend to affect the size of the partial correlations. In addition, building on Streb et al (2012), I find that more fine-grained election coding is associated with stronger political budget cycles, and that controlling both for pre- and post-election periods may be necessary, at least for public spending.

Meta-analyses can also test for publication bias. There is evidence that many bodies of literature in the social sciences suffer from that bias (Stanley and Doucouliagos 2012). To see if this is true for political budget cycles, I performed a series of simple tests to explore whether the size of the overall political budget cycle effect remains robust to various measures of article and journal quality, as measured by a journal's impact factor 10 To be brief, the results are not reported here but are available in the Supplemental Materials. I find evidence that publication bias exists in the literature. However, the existence of political cycles across the four budget categories remains robust after accounting for such bias. I also find that budgetary surpluses remain the most manipulated budget category during elections.

\footnotetext{
${ }^{10}$ These are a regression of journal quality on precision, the precision-effect/funnel asymmetry (PET-FAT) test, and the precision effect estimate with standard error (PEESE).
} 


\section{Conclusion}

This paper was motivated by the importance of addressing the conflicting theories, literature reviews, and inconclusive empirical results on political budget cycles. By combining all available studies over the last 15 years, a meta-analytic approach offered an ideal way to synthesize our knowledge of this topic. The meta-analysis herein does not provide conclusive evidence that political budget cycles exist in every context. Factors such as the quality of government institutions and fiscal transparency could not by analyzed in this paper. Moreover, exploring the magnitudes of conditional relationships (interactions) is difficult when using meta-regression analysis. Still, this paper goes beyond qualitative literature reviews by summarizing and evaluating the current state of the empirical literature, as well as by identifying the circumstances under which we are more or less likely to observe political budget cycles. Rather than relying on a single dataset, by aggregating multiple study results I was able to identify the extent to which particular study-, methodological-, and data-specific choices affect the evidence for political budget cycles. I investigated these differences across four different types of commonly studied variables in a number of ways, including testing for publication bias, using Bayesian model averaging, and calculating and plotting the sizes of the overall effects across budgetary subcategories.

Several important conclusions were reached. First, the strongest evidence for political budget cycles appears to be for public budget balance (the "fiscal stance"). Second, the lack of evidence in disaggregated expenditure categories suggests either that no effect exists, or that scholars have not yet pinned down a mediating variable that explains why these categories are manipulated only at certain times. Third, while the results are robust across many types of data and coding decisions, dynamics appear to be an important component to account for across all meta-regression results. Fourth, I find evidence that context matters. While this issue has been discussed widely in the literature, differences in data and methodology have made identifying particularly important 
contextual elements (or comparing them while controlling for other factors) difficult. The results reported herein also suggest that the level of government at which the election is held, as well as the level of temporal aggregation, may merit further investigation. Last, although publication bias exists in the literature, the size of the overall effect remains robust to this bias.

The purpose of this paper was to begin reconciling the conflicting state of the political budget cycle literature. Results from the meta-analysis suggest that although budget cycles are present in expenditures, revenues, fiscal balance, and debt, the effect is substantively small. The results also indicate the importance of accounting for context-conditional situations as well as controlling for study- and data-specific factors when probing the robustness of future empirical studies. Scholars of political economy should take note since meta-regression analysis suggests the necessity of making cross-study comparisons more carefully. Responding to a recent question posed by Klomp and De Haan (2013b, p. 329), “do political budget cycles really exist?”- the answer appears to be yes, but they are small and depend on a number of factors that must be taken into account. 


\section{References}

Aguinis H, Gottfredson RK, Wright TA (2011) Best-practice recommendations for estimating interaction effects using meta-analysis. Journal of Organizational Behavior 32(8):1033-1043

Ahmadov AK (2014) Oil, democracy, and context: A meta-analysis. Comparative Political Studies 47(9):1238-1267

Aidt TS, Mooney G (2014) Voting suffrage and the political budget cycle: Evidence from the london metropolitan boroughs 1902-1937. Journal of Public Economics 112:53-71

Aidt TS, Veiga FJ, Veiga LG (2011) Election results and opportunistic policies: A new test of the rational political business cycle model. Public Choice 148(1-2):21-44

Alesina A, Roubini N (1992) Political cycles in oecd economies. The Review of Economic Studies 59(4):663-688

Alt JE, Lassen DD (2006a) Fiscal transparency, political parties, and debt in oecd countries. European Economic Review 50(6):1403-1439

Alt JE, Lassen DD (2006b) Transparency, political polarization, and political budget cycles in oecd countries. American Journal of Political Science 50(3):530-550

Alt JE, Rose S (2009) Context-conditional political budget cycles. In: Boix C, Stokes SC (eds) The Oxford handbook of comparative politics, Oxford University Press, chap 34, pp 845-867

Barberia LG, Avelino G (2011) Do political budget cycles differ in latin american democracies? Economía pp 101-146

Borenstein M, Hedges LV, Higgins JP, Rothstein HR (2011) Introduction to meta-analysis. John Wiley \& Sons 
Brender A, Drazen A (2005) Political budget cycles in new versus established democracies. Journal of Monetary Economics 52(7):1271-1295

Brender A, Drazen A (2013) Elections, leaders, and the composition of government spending. Journal of Public Economics 97:18-31

Chang EC (2008) Electoral incentives and budgetary spending: Rethinking the role of political institutions. The Journal of Politics 70(04):1086-1097

Cohen J (2013) Statistical power analysis for the behavioral sciences, 2nd edn. Routledge

De Haan J, Klomp J (2013) Conditional political budget cycles: A review of recent evidence. Public Choice 157(3-4):387-410

Doucouliagos H, Ulubaşoğlu MA (2008) Democracy and economic growth: A meta-analysis. American Journal of Political Science 52(1):61-83

Drazen A, Eslava M (2010) Electoral manipulation via voter-friendly spending: Theory and evidence. Journal of Development Economics 92(1):39-52

Dubois E (2016) Political business cycles 40 years after nordhaus. Public Choice 166(1-2):235-259

Enkelmann S, Leibrecht M (2013) Political expenditure cycles and election outcomes: Evidence from disaggregation of public expenditures by economic functions. Economics Letters 121(1):128-132

Feldkircher M, Zeugner S (2009) Benchmark priors revisited: On adaptive shrinkage and the supermodel effect in bayesian model averaging. IMF Working Papers

Fernandez C, Ley E, Steel MF (2001) Benchmark priors for bayesian model averaging. Journal of Econometrics 100(2):381-427 
Franzese RJJ (2000) Electoral and partisan manipulation of public debt in developed democracies, 1956-1990. In: Strauch R, Hagen JV (eds) Institutions, Politics and Fiscal Policy, Kluwer Academic Press, Dordrecht, pp 61-83

Franzese RJJ (2002) Electoral and partisan cycles in economic policies and outcomes. Annual Review of Political Science 5(1):369-421

Galli E, Rossi SP (2002) Political budget cycles: The case of the western german länder. Public Choice 110(3-4):283-303

Gonzalez MdlA (2002) Do changes in democracy affect the political budget cycle? evidence from mexico. Review of Development Economics 6(2):204-224

Hanusch M (2012) Coalition incentives for political budget cycles. Public Choice 151(1):121-136

Hibbs DAJ (1977) Political parties and macroeconomic policy. American Political Science Review pp 1467-1487

Hunter JE, Schmidt FL (2004) Methods of meta-analysis: Correcting error and bias in research findings. Sage

Hyde SD, O’Mahony A (2010) International scrutiny and pre-electoral fiscal manipulation in developing countries. The Journal of Politics 72(03):690-704

Imbeau LM, Pétry F, Lamari M (2001) Left-right party ideology and government policies: A metaanalysis. European Journal of Political Research 40(1):1-29

Iršová Z, Havránek T (2013) Determinants of horizontal spillovers from fdi: Evidence from a large meta-analysis. World Development 42:1-15 
John P, Ward H (2001) Political manipulation in a majoritarian democracy: Central government targeting of public funds to english subnational government, in space and across time. The British Journal of Politics \& International Relations 3(3):308-339

Katsimi M, Sarantides V (2012) Do elections affect the composition of fiscal policy in developed, established democracies? Public Choice 151(1-2):325-362

Khemani S (2004) Political cycles in a developing economy: Effect of elections in the indian states. Journal of Development Economics 73(1):125-154

Klomp J, De Haan J (2013a) Conditional election and partisan cycles in government support to the agricultural sector: An empirical analysis. American Journal of Agricultural Economics 95(4):793-818

Klomp J, De Haan J (2013b) Do political budget cycles really exist? Applied Economics 45(3):329-341

Kneebone RD, McKenzie KJ (2001) Electoral and partisan cycles in fiscal policy: An examination of canadian provinces. International Tax and Public Finance 8(5-6):753-774

Lau RR, Sigelman L, Rovner IB (2007) The effects of negative political campaigns: A metaanalytic reassessment. Journal of Politics 69(4):1176-1209

Ley E, Steel MF (2009) On the effect of prior assumptions in bayesian model averaging with applications to growth regression. Journal of Applied Econometrics 24(4):651-674

Moeltner K, Woodward R (2009) Meta-functional benefit transfer for wetland valuation: Making the most of small samples. Environmental and Resource Economics 42(1):89-108

Nordhaus WD (1975) The political business cycle. Review of Economic Studies 42(2) 
Padovano F (2012) The drivers of interregional policy choices: Evidence from italy. European Journal of Political Economy 28(3):324-340

Persson T, Tabellini GE (1990) Macroeconomic policy, credibility and politics, vol 38. Taylor \& Francis

Persson T, Tabellini GE (2005) The economic effects of constitutions. MIT press

Rogoff KS (1990) Equilibrium political budget cycles. National Bureau of Economic Research Cambridge, Mass, USA

Rose S (2006) Do fiscal rules dampen the political business cycle? Public Choice 128(3-4):407431

Sáez L, Sinha A (2010) Political cycles, political institutions and public expenditure in india, 19802000. British Journal of Political Science 40:91-113

Sakurai SN, Menezes-Filho N (2011) Opportunistic and partisan election cycles in brazil: New evidence at the municipal level. Public Choice 148(1-2):233-247

Sánchez-Meca J, Marín-Martínez F (2008) Confidence intervals for the overall effect size in random-effects meta-analysis. Psychological Methods 13(1):31

Schuknecht L (2000) Fiscal policy cycles and public expenditure in developing countries. Public Choice 102(1-2):113-128

Schultz KA (1995) The politics of the political business cycle. British Journal of Political Science 25(1):79-100

Shi M, Svensson J (2006) Political budget cycles: Do they differ across countries and why? Journal of Public Economics 90(8):1367-1389 
Sjahrir BS, Kis-Katos K, Schulze GG (2013) Political budget cycles in indonesia at the district level. Economics Letters 120(2):342-345

Smets K, Van Ham C (2013) The embarrassment of riches? a meta-analysis of individual-level research on voter turnout. Electoral Studies 32(2):344-359

Stanley TD (2001) Wheat from chaff: Meta-analysis as quantitative literature review. Journal of Economic Perspectives pp 131-150

Stanley TD, Doucouliagos H (2012) Meta-regression analysis in economics and business, vol 5. Routledge

Streb JM, Torrens G (2013) Making rules credible: Divided government and political budget cycles. Public Choice 156(3-4):703-722

Streb JM, Lema D, Torrens G (2009) Checks and balances on political budget cycles: Crosscountry evidence. Kyklos 62(3):426-447

Streb JM, Lema D, Garofalo P (2012) Temporal aggregation in political budget cycles. Economía pp 39-78

Veiga LG (2012) Determinants of the assignment of eu funds to portuguese municipalities. Public Choice 153(1-2):215-233

Vergne C (2009) Democracy, elections and allocation of public expenditures in developing countries. European Journal of Political Economy 25(1):63-77 